\title{
Bcr/Abl Expression Stimulates Integrin Function in Hematopoietic Cell Lines
}

\author{
Gianfranco Bazzoni, ${ }^{*}$ Nadia Carlesso, ${ }^{\ddagger}$ James D. Griffin, ${ }^{\ddagger}$ and Martin E. Hemler* \\ $*$ Division of Tumor Virology, and ${ }^{\ddagger}$ Laboratory of Hematologic Malignancies, Dana-Farber Cancer Institute, Harvard Medical School, \\ Boston, Massachusetts 02115
}

\begin{abstract}
Cell adhesion to the extracellular matrix is largely mediated by adhesion molecules of the integrin family and is often diminished upon oncogenic transformation. However, we show here that the chronic myelogenous leukemia oncogene $\mathrm{Bcr} /$ Abl has positive effects on VLA-4 and VLA-5 integrin function. The presence of Bcr/Abl in the GM-CSF- or IL-3-dependent hematopoietic cell lines MO7e, 32D, and $\mathrm{BaF} / 3$ enhanced cell binding to both soluble and immobilized fibronectin. The effect was due to enhanced function of the VLA-5 integrin fibronectin receptor and not to increased surface expression. In parallel, Bcr/Abl stimulated cell adhesion to the VLA-4 integrin ligand VCAM-1. Stimulation of VLA-5 function directly correlated with induction of Bcr/Abl tyrosine kinase activity in a temperature-sensitive kinase mutant. Thus, Bcr/Abl stimulates integrin-dependent cell adhesion, by a mechanism involving increased ligand binding, with the tyrosine kinase activity of Bcr/Abl likely playing a key role. Consistent with these results, hematopoietic precursor cells from chronic myelogenous leukemia patients also showed increased adhesion to fibronectin. (J. Clin. Invest. 1996. 98:521-528.) Key words: integrin • Bcr/Abl • cell adhesion • chronic myelogenous leukemia • fibronectin
\end{abstract}

\section{Introduction}

Integrins are heterodimeric cell surface molecules that mediate cell adhesion and link extracellular ligands with cytoskeletal proteins $(1,2)$, and also may affect cell homeostasis by influencing the rate of cell proliferation (3) and cell death (4). Integrin function can be regulated, without changes in surface levels, such as during platelet aggregation (5), lymphocyte activation $(6,7)$, and keratinocyte differentiation (8). This process, known as "inside-out" signaling (9), may involve integrin clustering, modulation of ligand binding affinity, and association with the cytoskeleton (9).

Abnormal adhesive properties of neoplastic cells are often due to alteration of integrin function (1). Altered integrin function may also occur in chronic myelogenous leukemia (CML) ${ }^{1}$

The first two authors contributed equally to this study.

Address correspondence to Martin E. Hemler, Ph.D., Dana-Farber Cancer Institute, Room M-613, 44 Binney Street, Boston, MA 02115. Phone: 617-632-3410; FAX: 617-632-2662; E-mail: Martin_Hemler@ DFCI.HARVARD.EDU

Received for publication 18 December 1995 and accepted in revised form 13 May 1996.

1. Abbreviation used in this paper: $\mathrm{CML}$, chronic myelogenous leukemia.

J. Clin. Invest.

(C) The American Society for Clinical Investigation, Inc.

0021-9738/96/07/0521/08 \$2.00

Volume 98, Number 2, July 1996, 521-528 cells. CML is a myeloproliferative disorder associated with expression of the $\mathrm{Bcr} / \mathrm{Abl}$ oncogene, a hybrid gene created by the Philadelphia chromosome translocation (10), juxtaposing the $B C R$ and c- $A B L$ genes (located on chromosomes 22 and 9, respectively) to generate the fusion protein p210 Bcr/Abl. Compared with $\mathrm{c}-a b l$, the $\mathrm{Bcr} / \mathrm{Abl}$ gene product has a higher tyrosine kinase activity that is essential for transformation (11). Compared with normal hematopoietic progenitors, progenitors from CML show decreased colony formation after adhesion to bone marrow stroma and/or fibronectin $(12,13)$. Thus it was suggested that Bcr/Abl might downregulate integrin-mediated adhesive activity. However, the specific effect of $\mathrm{Bcr} / \mathrm{Abl}$ expression on integrin function has not been directly evaluated. In this study we have determined directly the effects of p210 Bcr/Abl on both integrin-mediated adhesion to immobilized ligand and integrin binding of soluble ligand.

\section{Methods}

Cell lines and cell cultures. The human cell line MO7e (obtained from Steve Clark, Genetics Institute, Cambridge, MA) was derived from a patient with megakaryocytic leukemia and does not constitutively express Bcr/Abl. Although immortal, the MO7e cell line is completely dependent on GM-CSF or IL-3 for proliferation and viability. MO7e cells were cultured in RPMI-1640 (Mediatech, Washington, DC) supplemented with $10 \%$ FBS and $1 \mathrm{ng} / \mathrm{ml}$ human GM-CSF (Genetics Institute). The murine myeloid progenitor cell line 32Dcl3 (32D) was obtained from Dr. J. Greenberger (University of Pittsburgh, Pittsburgh, PA). Bcr/Abl makes the 32D cell line leukemic in syngeneic mice where it is rapidly lethal (14). The murine $\mathrm{BaF} / 3$ progenitor cell line (from Dr. A. D'Andrea, Dana-Farber Cancer Institute) has characteristics of immature $\mathrm{B}$ cells. Both 32D and $\mathrm{BaF} / 3$ cells depend on IL-3 for growth and viability. Both lines were cultured in RPMI-1640 supplemented with 10\% FBS, and 10\% WEHI-3B conditioned medium as a source of murine IL-3.

The p210 Bcr/Abl expression vector, pGDp210Bcr/Abl, was obtained from Dr. G. Daley and Dr. D. Baltimore (Massachusetts Institute of Technology, Cambridge, MA). The p210 Bcr/Abl temperature-sensitive mutant pGDp210Bcr/Abl-TS1 was generated by introducing the two point mutations $\mathrm{Arg}^{457} \rightarrow$ His and $\mathrm{Tyr}^{469} \rightarrow$ His in the tyrosine kinase domain of $\mathrm{Abl}$, as described (15), and cloned into the expression vector pGD. Sublines expressing pGDp210Bcr/Abl or pGDp210Bcr/Abl-TS1 were generated by transfection of the corresponding plasmids into $\mathrm{MO} 7 \mathrm{e}, 32 \mathrm{D}$, and $\mathrm{BaF} / 3$ cell lines by electroporation, using a Gene Pulser (Bio-Rad, Richmond, CA) and selected with G418 as described (15). Cell lines transfected with pGDp210Bcr/ Abl became factor independent and were cultured in RPMI-1640 supplemented with $10 \%$ FBS. 32D cells transfected with pGDp210Bcr/ Abl-TS1 were not factor independent when cultured at the nonpermissive temperature $\left(39^{\circ} \mathrm{C}\right)$, and proliferation required the addition of $10 \%$ WEHI-3B conditioned medium.

Adhesion assays. Cell adhesion to fibronectin was carried out as previously described (16). Briefly, soluble human fibronectin (GIBCOBRL, Gaithersburg, MD) was coated onto 96-well microtiter plates (Flow Laboratories, Inc., McLean, VA) and incubated overnight at $4^{\circ} \mathrm{C}$. Then $0.1 \%$ heat-denatured BSA was added for 45 min to block nonspecific adhesion. After culturing in the presence or absence of IL-3 or GM-CSF for $16 \mathrm{~h}$, cells were labeled by incubation with the 


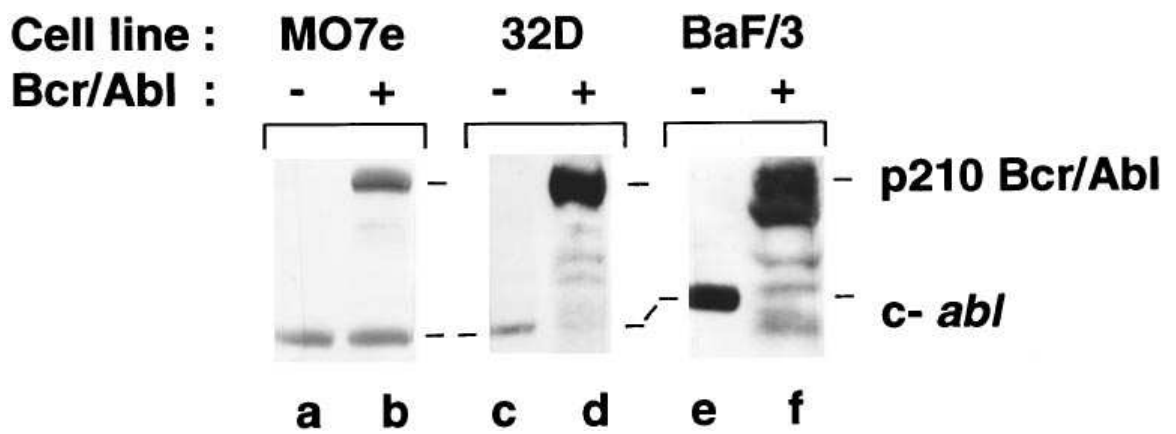

Figure 1. Expression of p210 Bcr/Abl on hematopoietic cell lines. Lysates from untransfected (lanes $a, c$, and $e$ ) and Bcr/Abl-transfected (lanes $b, d$, and $f$ ) MO7e, 32D, and $\mathrm{BaF} / 3$ cells were fractionated on a $7.5 \%$ SDSpolyacrylamide gel and immunoblotted with an anti-Abl antibody. Notably, c- $a b l$ expression was decreased in Bcr/Abl-transfected 32D and $\mathrm{BaF} / 3$ cells (lanes $d$ and $f$ ). Also, degraded fragments of $\mathrm{Bcr} / \mathrm{Abl}$ are present, particularly in lanes $d$ and $f$. fluorescent dye BCECF-AM (Molecular Probes, Inc., Eugene, OR) for $30 \mathrm{~min}$ at $37^{\circ} \mathrm{C}$ and then washed twice before resuspending in RPMI-1640 containing $0.1 \%$ heat-inactivated BSA. After evaluating cell viability by trypan blue exclusion, cells $\left(5 \times 10^{4} /\right.$ well $)$ were added to each well in triplicate and incubated for $30 \mathrm{~min}$ at $37^{\circ} \mathrm{C}$. Plates were then washed three times with RPMI to remove unbound cells. Cells remaining attached to the plates were analyzed using a fluorescence analyzer (Cytofluor 2300; Millipore Corp., Bedford, MA). After subtraction of background cell binding to BSA-coated wells, values for cells bound $/ \mathrm{mm}^{2}$ were calculated as described (17).

For adhesion of 32D cells transfected with pGDp210Bcr/AblTS1, cytokine-deprived cells were grown at either nonpermissive $\left(39^{\circ} \mathrm{C}\right)$ or permissive $\left(33^{\circ} \mathrm{C}\right)$ temperatures for $16 \mathrm{~h}$, and then adhesion was carried out at either 33 or $39^{\circ} \mathrm{C}$. For VCAM- 1 adhesion assays, the purified VCAM-1-mouse C kappa fusion protein $(2 \mu \mathrm{g} / \mathrm{ml})$ was added (for $30 \mathrm{~min}$ at $37^{\circ} \mathrm{C}$ ) to 96 -well plates that had been precoated overnight with a rat antibody to mouse $\mathrm{C}$ kappa. For negative control experiments, wells were precoated, but VCAM-1 was omitted.

For the comparison of normal and CML progenitor cells, heparinized bone marrow samples were obtained, after informed consent, from two patients with newly diagnosed CML in chronic phase, and two healthy volunteers. Low density mononuclear cells were isolated using standard Ficoll centrifugation. CD34+ progenitor cells were obtained with an immunomagnetic isolation system (Dynal Co., Oslo, Norway) according to the manufacturer's instructions. CD34+ cells were cultured for $16 \mathrm{~h}$ in serum-free medium (AIM V; Gibco Laboratories, Grand Island, NY) in the absence of added IL-3, and then adhesion to fibronectin was evaluated as described above. The presence of $\mathrm{p} 210 \mathrm{Bcr} / \mathrm{Abl}$ in cells from CML patients was confirmed by RT-PCR.

Ligand binding assay. Cells were washed once with TBS (Trisbuffered saline: $24 \mathrm{mM}$ Tris- $\mathrm{HCl}, \mathrm{pH} 7.4,137 \mathrm{mM} \mathrm{NaCl}, 2.7 \mathrm{mM}$ $\mathrm{KCl}$ ), and preincubated at room temperature for 5 min with TBS containing $5 \%$ BSA and $0.02 \%$ sodium azide (washing buffer) and then, where indicated, with either GRGDSP peptide, fibronectin, or $\mathrm{MnCl}_{2}$. Aliquots of $10^{5}$ cells were then incubated for $45 \mathrm{~min}$ on ice with primary antibodies (ascites at a final dilution of 1:100, or purified $\mathrm{mAbs}$ at a final concentration of $1 \mu \mathrm{g} / \mathrm{ml}$ ). Cells were washed three times with washing buffer and incubated for $30 \mathrm{~min}$ on ice with FITCconjugated goat anti-mouse (GIBCO-BRL) or anti-rat IgG (Sigma Immunochemicals, St. Louis, MO). Cells were washed three times and analyzed using a FACScan machine (Becton Dickinson, Oxnard, CA).

Antibodies. The following $\mathrm{mAbs}$ against human integrins were used: mouse anti- $\alpha^{1}$, TS2/7 (18); anti- $\alpha^{2}$, A2-2E10 (19); anti- $\alpha^{3}$, A3IIF5 (20); anti- $\alpha^{4}$, B5G10 (21); anti- $\alpha^{6}$, A6-ELE (22); anti- $\beta_{1}$, TS2/16 (18) and A-1A5 (23); rat anti- $\alpha^{5}, \mathrm{mAb} 16$ (24); rat anti- $\beta_{1}, \mathrm{mAb} 13$ (24) and 9EG7 (25). Other mAbs were anti-mouse $\alpha^{4}$, MFR5; and $\alpha^{5}$, R1-2 (Pharmingen, San Diego, CA) and antimycoplasma control antibody J2A2 (26).

Immunoblotting. Cells $\left(10^{8}\right.$ cells $\left./ \mathrm{ml}\right)$ were lysed in a solution $(1 \%$

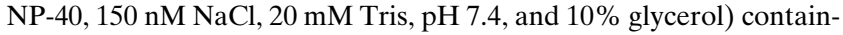
ing $1 \mathrm{mM}$ PMSF, $5 \mathrm{mM}$ aprotinin, and $1 \mathrm{mM} \mathrm{Na}_{3} \mathrm{VO}_{4}$. Lysates were adjusted to contain equal amounts of total protein, using the Brad- ford assay (Bio-Rad, Hercules, CA), and were boiled for $5 \mathrm{~min}$ in an equal volume of SDS sample buffer. Proteins were separated by $7.5 \%$ SDS-PAGE and electrophoretically transferred to nitrocellulose (Schleicher \& Schuell, Keene, NH). Immunoreactive bands were detected with an mAb against c- $A b l$ (gift of Dr. Naomi Rosenberg, Tufts University, Boston, MA) and visualized with alkaline phosphatase staining reagents.

\section{Results}

Expression of p210 Bcr/Abl increases cell adhesion to fibronectin. The hematopoietic cell lines MO7e, 32D, and $\mathrm{BaF} / 3$ were stably transfected with $\mathrm{Bcr} / \mathrm{Abl} \mathrm{cDNA}$ and the expression of p210 Bcr/Abl in transfected cells was confirmed by immunoblotting (Fig. 1). Then, adhesion to fibronectin was examined using MO7e, a GM-CSF-dependent human megakaryocytic leukemia cell line (27). Since GM-CSF (as well as IL-3) has been reported to stimulate cell adhesion (28), both untrans-

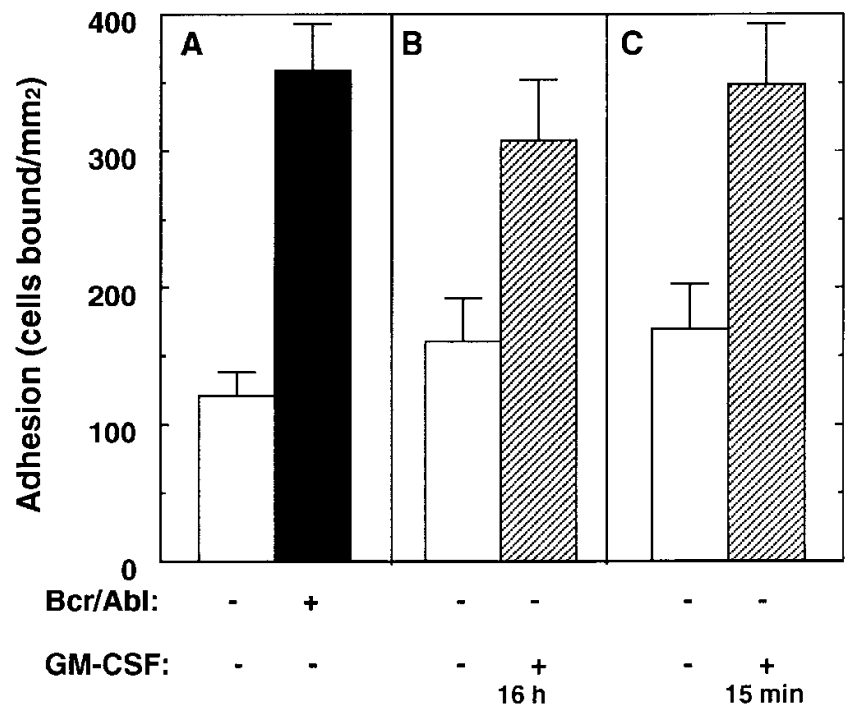

Figure 2. Bcr/Abl expression and GM-CSF stimulation induce adhesion of MO7e cells to fibronectin. (A) Untransfected (white bar) and p210 Bcr/Abl-transfected (black bar) MO7e cells were cultured for $16 \mathrm{~h}$ in the absence of GM-CSF before the adhesion assay. (B) Untransfected MO7e cells were cultured for $16 \mathrm{~h}$ before the adhesion assay either in absence (white bar) or in presence (striped bar) of $1 \mathrm{ng} /$ $\mathrm{ml}$ GM-CSF. (C) Untransfected MO7e cells were cultured for $16 \mathrm{~h}$ with no GM-CSF and then incubated for $15 \mathrm{~min}$ before adhesion with either buffer (white bar) or GM-CSF (striped bar). Results are mean \pm SD of a representative experiment performed in triplicate. 


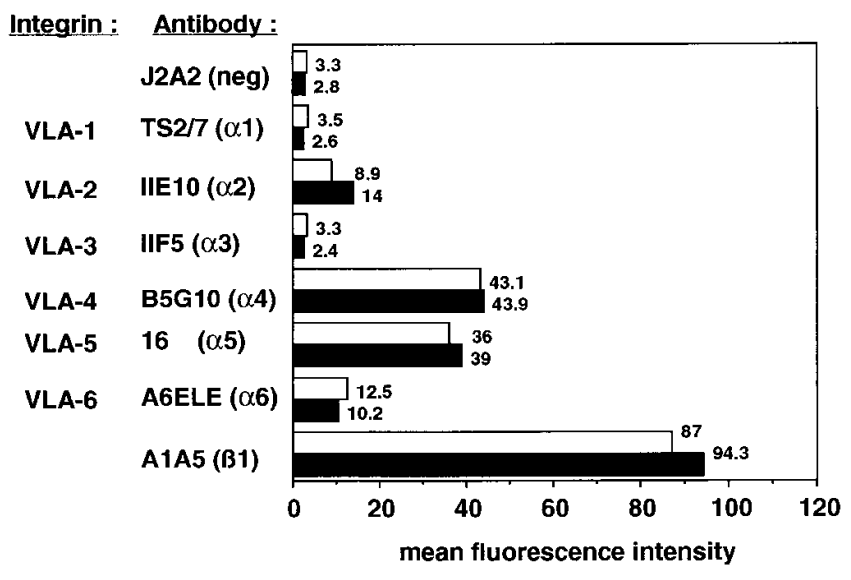

Figure 3. p210 Bcr/Abl does not affect $\beta_{1}$ integrin expression levels. Untransfected (white bars) and p210-Bcr/Abl-transfected (black bars) MO7e cells cultured in the absence of GM-CSF were incubated with $\mathrm{mAbs}$ directed against different integrin subunits. Analysis by flow cytometry yielded mean fluorescence intensity values as indicated at the right of each bar.

fected and Bcr/Abl-transfected MO7e cells were deprived of GM-CSF for $16 \mathrm{~h}$ before the adhesion assay. In this condition, $\mathrm{Bcr} / \mathrm{Abl}$ transfectants showed up to threefold higher adhesion than untransfected cells (Fig. $2 A$ ). In a parallel experiment, adhesion of untransfected cells was induced up to a level comparable with the Bcr/Abl transfectants, by preincubation with GM-CSF for $16 \mathrm{~h}$ (Fig. $2 \mathrm{~B}$ ). Also, short-term treatment with GM-CSF (15 min) induced comparable adhesion (Fig. $2 \mathrm{C}$ ), despite growth factor deprivation for $16 \mathrm{~h}$. Thus, factor deprivation for $16 \mathrm{~h}$ had no obvious effect on adhesive potential. Adhesion of MO7e cells was mediated by the integrin VLA-5 $\left(\alpha^{5} \beta_{1}\right)$, since it was completely inhibited by either anti- $\alpha^{5} \mathrm{mAb}$ 16 or anti- $\beta_{1}$ mAb 13 (not shown).

The effect of p210 Bcr/Abl expression was not due to upregulation of VLA-5 expression, since comparable levels of VLA-5 were expressed at the surface of both parental and transfected MO7e cells, as determined by flow cytometry (Fig. $3)$. Furthermore, there were no changes in the expression of other $\beta_{1}$ integrins. On both cell types we detected high levels of VLA-4 and -5, low levels of VLA-2 and -6, and negligible amounts of VLA-1 and -3 .

We next analyzed the effect of Bcr/Abl expression on the functions of two nonleukemic, IL-3-dependent, murine cell lines, 32D and $\mathrm{BaF} / 3$, derived from normal bone marrow cultures $(29,30)$. In the absence of IL-3, adhesion of 32D cells was very low even at the highest concentrations of fibronectin. In comparison, adhesion of the $\mathrm{Bcr} / \mathrm{Abl}$ transfectants was greatly elevated at all levels of fibronectin tested. Culture for $16 \mathrm{~h}$ in IL-3 strongly increased adhesion of parental 32D cells, but had no further effect on the already adhesive Bcr/Abl-transfected cells (Fig. $4 A$ ). No differences in cell viability were observed between parental and transfected cells either in presence or in absence of IL-3 (not shown). Brief incubation $\left(15 \mathrm{~min}\right.$ at $37^{\circ} \mathrm{C}$ ) of factor-starved 32D cells with IL-3 had effects (not shown) similar to preincubation with IL-3 for $16 \mathrm{~h}$. Bcr/Abl expression similarly increased the adhesion to fibronectin $(5 \mu \mathrm{g} / \mathrm{ml})$ of IL-3-deprived $\mathrm{BaF} / 3$ cells from $595 \pm 90$ up to $829 \pm 48$ cells bound $/ \mathrm{mm}^{2}$ in a representative experiment.
A
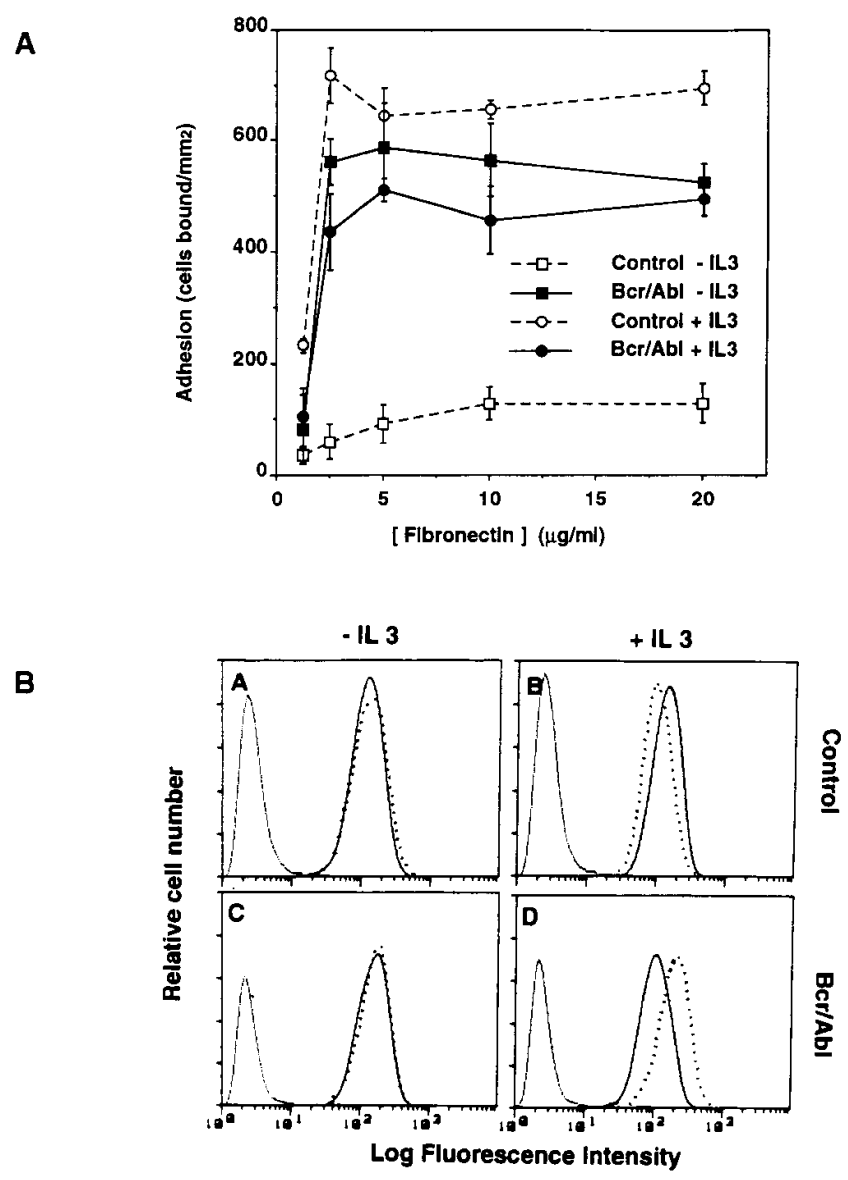

Figure 4. Effects of p210 Bcr/Abl and IL-3 on 32D cell adhesion to fibronectin and integrin expression. (A) Untransfected (open symbols) and p210 Bcr/Abl-transfected (closed symbols) 32D cells were cultured for $16 \mathrm{~h}$ either in absence (squares) or presence (circles) of IL-3 before the adhesion assay. Results are mean \pm SD of a representative experiment performed in triplicate. (B) Untransfected (top panels) and p210 Bcr/Abl-transfected (bottom panels) cells were preincubated for $16 \mathrm{~h}$ either in the absence (left panels) or presence (right panels) of IL-3, and then stained with an irrelevant antibody (tight dotted line), anti-mouse $\alpha 4 \mathrm{mAb} \mathrm{R} 1-2$ (sparse dotted line), or $\alpha 5 \mathrm{mAb}$ MFR-5 (solid line) and analyzed by flow cytometry.

Adhesion of 32D cells to fibronectin was inhibited by the anti-mouse- $\alpha^{5}$ mAb MFR-5 (not shown). The VLA-5 expression levels were similar in untransfected and Bcr/Abl-transfected cells, both in the absence or presence of IL-3 (Fig. $4 \mathrm{~B}$ ). Adhesion was maximal within $30 \mathrm{~min}$ of exposure to immobilized fibronectin, but declined after $2 \mathrm{~h}$ and even further after $6 \mathrm{~h}$ (Fig. 5). Regardless of whether 32D cells expressed Bcr/ Abl, or were stimulated by IL-3, a similar adhesion time course was observed (Fig. 5).

Besides VLA-5, 32D cells express the VLA-4 $\left(\alpha^{4} \beta_{1}\right)$ integrin (Fig. $4 \mathrm{~B}$ ) and this integrin mediated 32D cell adhesion to the VLA-4 ligand VCAM-1 (376 \pm 25 cells bound $\left./ \mathrm{mm}^{2}\right)$. Adhesion was increased both in the Bcr/Abl transfectants (in absence of IL-3) and in untransfected cells that had been pretreated with IL-3 (up to $669 \pm 31$ and $654 \pm 16$ cells bound $/ \mathrm{mm}^{2}$, respectively). Bcr/Abl transfection or IL-3 treatment had minimal effects on VLA-4 expression (Fig. $4 B$ ).

Activation of p $210 \mathrm{Bcr} / \mathrm{Abl}$ kinase activity stimulates adhesion of $32 \mathrm{D}$ cells to fibronectin. To analyze further the mecha- 


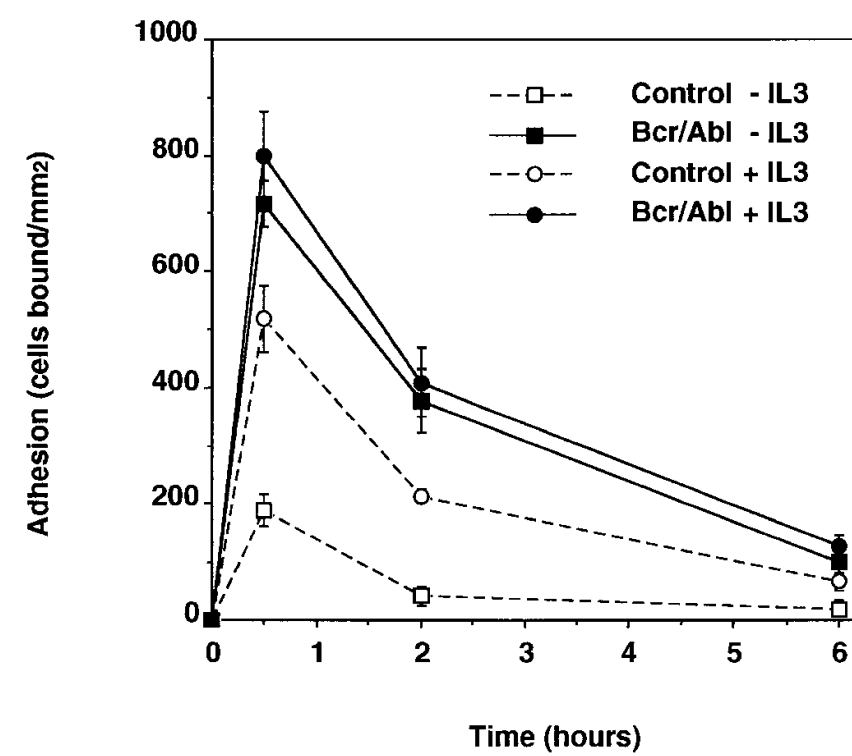

Figure 5. Time-dependent adhesion of 32D cells to fibronectin. Untransfected (open symbols) and p210 Bcr/Abl-transfected (closed symbols) 32D cells were cultured for $16 \mathrm{~h}$ either in absence (squares) or presence (circles) of IL-3 before the adhesion assay. Adhesion to fibronectin $(5 \mu \mathrm{g} / \mathrm{ml})$ was evaluated at the time points indicated. Results are mean \pm SD from triplicate determinations.

nism of Bcr/Abl-dependent stimulation of integrin function, we examined cell adhesion in $32 \mathrm{D}$ cells transfected with a temperature-sensitive form of p210 Bcr/Abl kinase (15). At the nonpermissive temperature $\left(39^{\circ} \mathrm{C}\right)$ kinase activity is minimal, and in the absence of IL-3, only low to moderate adhesion to fibronectin was seen in two different clones (Fig. 6, $A$ and $B$ ). However, adhesion was markedly upregulated at the $33^{\circ} \mathrm{C}$ permissive temperature when the kinase was active. In the pres- ence of IL-3, induction of Bcr-Abl kinase activity had less of an effect, because adhesion of both clones already showed nearly maximal stimulation (Fig. 6, $A$ and $B$ ). In a control experiment, adhesion to fibronectin of $32 \mathrm{D}$ cells (either untransfected or transfected with wild-type p210 Bcr/Abl) was not significantly different at either 39 or $33^{\circ} \mathrm{C}$ (Fig. $6 \mathrm{C}$ ). Therefore, the differences in adhesion detected with the temperature-sensitive p210 Bcr/Abl mutants are not due to a nonspecific temperature effect on cell adhesion. Stimulation of adhesion correlated with induction of Bcr/Abl kinase activity (Fig. 7). Switching from 39 to $33^{\circ} \mathrm{C}$ for $6 \mathrm{~h}$ increased cell adhesion to fibronectin and induced in parallel p210 Bcr/Abl autophosphorylation. Only low levels of adhesion and phosphorylation were detected in cells kept at $39^{\circ} \mathrm{C}$ throughout the assay.

Expression of $210 \mathrm{Bcr} / \mathrm{Abl}$ stimulates binding of soluble fibronectin. Regulation of integrin-mediated adhesion may occur by mechanisms that involve alterations in ligand binding affinity (e.g., reference 31). To determine whether Bcr/Abl and growth factors directly modulate integrin binding to fibronectin, we exploited the ability of the mAb 9EG7 to detect a conformational change of the $\beta_{1}$ integrin subunit induced upon ligand binding (32). Both untransfected and Bcr/Abltransfected 32D cells were incubated with the ligand mimetic peptide GRGDSP and analyzed by flow cytometry for expression of the 9EG7 epitope. In the absence of IL-3, very low levels of the epitope were induced as a result of peptide binding to untransfected cells. However, 9EG7 expression was induced nearly threefold on the Bcr/Abl transfectants. IL-3 stimulated 9EG7 expression on nontransfected cells, but had minimal effect on the Bcr/Abl transfectants which appeared to be already maximally activated (Fig. $8 A$ ). Bcr/Abl expression also greatly stimulated the binding of $250 \mathrm{nM}$ soluble fibronectin (Fig. 8 $B$ ). Also in Fig. $8 B$, as seen in Fig. $8 A$, the addition of IL-3 could stimulate untransfected control cells, but Bcr/Abl-transfected cells already showed near maximal fibronectin binding, as measured by $9 \mathrm{EG} 7$ epitope induction.
32D cells transfected with temperature-sensitive p210 Bcr/Abl kinase

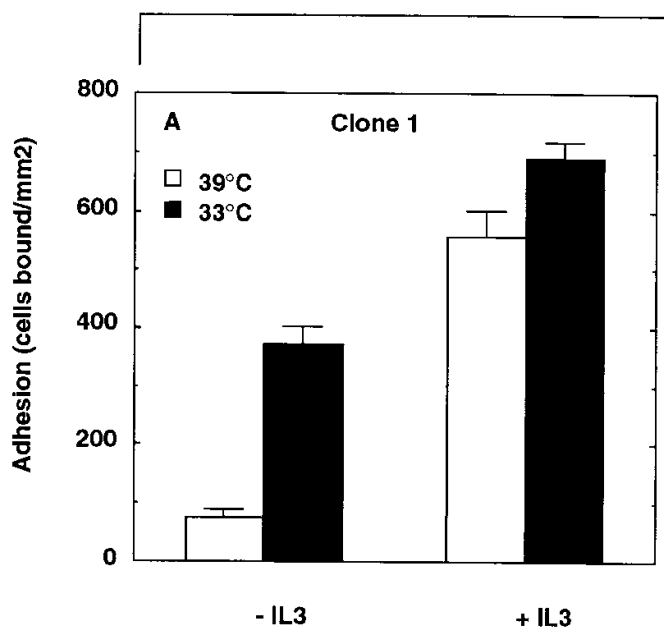

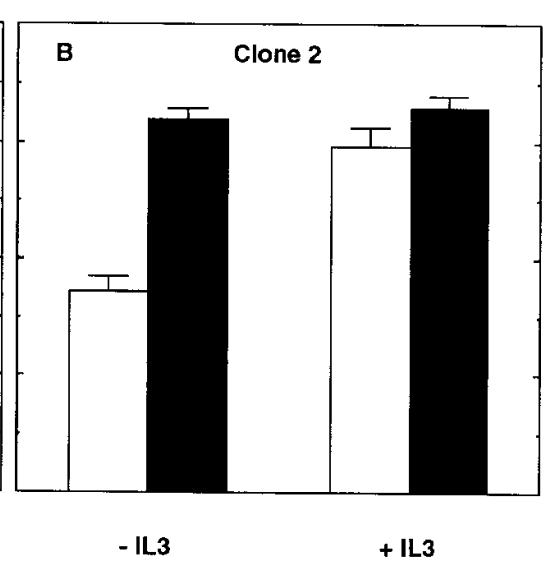

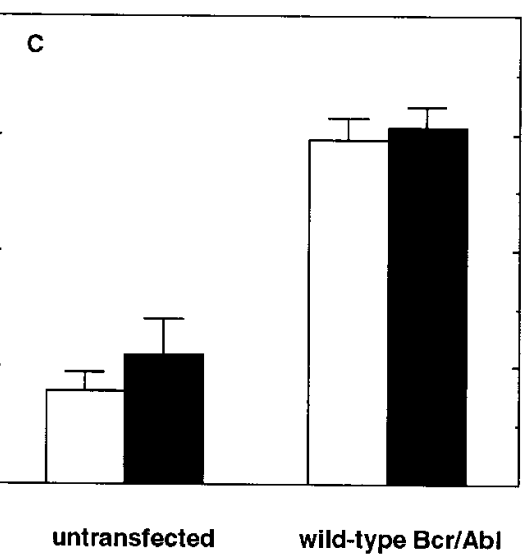

Figure 6. Activation of $\mathrm{p} 210 \mathrm{Bcr} / \mathrm{Abl}$ kinase stimulates adhesion of 32D cells to fibronectin. Two clones of 32D cells $(A$ and $B)$, transfected with a temperature-sensitive form of $\mathrm{p} 210 \mathrm{Bcr} / \mathrm{Abl}$ kinase, were incubated for $16 \mathrm{~h}$ in the absence or in the presence of IL-3 and tested for adhesion to fibronectin $(5 \mu \mathrm{g} / \mathrm{ml})$. Both the 16-h incubation and the subsequent adhesion assay were carried out at either nonpermissive $\left(39^{\circ} \mathrm{C} ;\right.$ white bars) or permissive $\left(33^{\circ} \mathrm{C}\right.$; black bars $)$ temperature. In a parallel control experiment $(C)$, the adhesion of untransfected and wild-type p210 Bcr/Abl-transfected $32 \mathrm{D}$ cells was evaluated at either 39 or $33^{\circ} \mathrm{C}$. Results are mean $\pm \mathrm{SD}$ of a representative experiment performed in triplicate. 


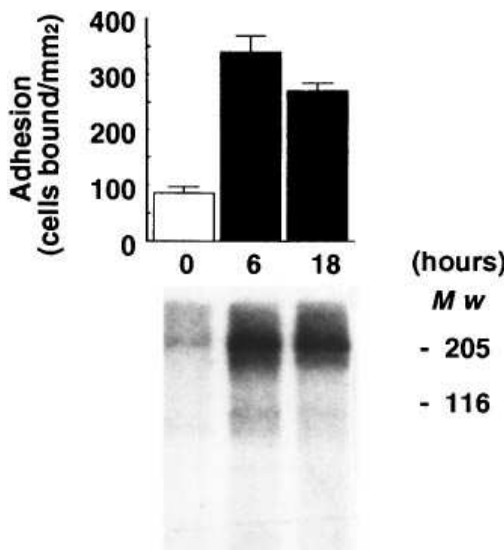

Figure 7. Induction of p210 Bcr/Abl kinase activity correlates with stimulation of cell adhesion. 32D cells transfected with temperature-sensitive p210 Bcr/ Abl kinase (clone 1) were incubated at $39^{\circ} \mathrm{C}$ before switching to $33^{\circ} \mathrm{C}$ for the indicated times. Cells were then tested for adhesion to 5 $\mu \mathrm{g} / \mathrm{ml}$ fibronectin (top panel). In parallel, ${ }^{32} \mathrm{P}-$-labeled cell lysates were immunoprecipi-

tated with an anti-Abl antibody and separated by SDS-PAGE to test autophosphorylation of Bcr/Abl (bottom).

The low expression of the epitope on untransfected cells was not due to an intrinsic defect of the integrin molecule. Indeed, when cells were treated with $5 \mathrm{mM}$ manganese instead of soluble ligand, the epitope could be induced at comparable levels in both parental and transfected cells, either in the presence or absence of IL-3 (Fig. $8 \mathrm{C}$ ). Like integrin ligands, manganese was previously found to induce the $9 \mathrm{EG} 7^{+}$conformation (32).

Adhesion of CML progenitor cells to fibronectin. We also analyzed the adhesive properties of $\mathrm{CD}^{+} 4^{+}$hematopoietic precursors obtained from CML patients compared with those from normal individuals. In two separate experiments, the $\mathrm{CD} 4^{+}$bone marrow precursors from CML patients showed elevated adhesion to fibronectin (Fig. 9). The cumulative results show that adhesion of CML precursors is elevated by nearly twofold. These results represent 12 adhesion assay data points for normal progenitors, and 9 data points for CML progenitors.

\section{Discussion}

To understand the molecular mechanisms responsible for the altered adhesiveness of hematopoietic progenitors in CML
$(12,13)$, we evaluated $\mathrm{Bcr} / \mathrm{Abl}$ effects on integrin function in several model hematopoietic cell lines. We observed that: $(a)$ p210 Bcr/Abl expression strongly enhances adhesion (in a 30-min assay) of hematopoietic cells to fibronectin and VCAM-1 mediated by the integrins VLA-5 and VLA-4; $(b)$ the proadhesive effects of Bcr/Abl closely mimic the proadhesive effects of GM-CSF and IL-3; (c) the Bcr/Abl effect is at least partially due to enhanced ligand binding activity; $(d)$ the tyrosine kinase activity of $\mathrm{Bcr} / \mathrm{Abl}$ is necessary for its effect on cell adhesion; and $(e) \mathrm{Bcr} / \mathrm{Abl}$ effects in cell lines correlate with increased adhesion seen in CML progenitor cells.

Bcr/Abl stimulates integrin-mediated cell adhesion. The stimulatory effects of $\mathrm{Bcr} / \mathrm{Abl}$ on cell adhesion were verified using three different cell lines transfected with the Bcr/Abl oncogene. In the human megakaryocytic leukemia cell line MO7e, in the murine myeloid progenitor line $32 \mathrm{D}$, and in the murine lymphoid progenitor line $\mathrm{BaF} / 3$, the effects of $\mathrm{Bcr} / \mathrm{Abl}$ on adhesion to fibronectin were remarkably similar. For each of these lines, the untransfected parental cell provides an ideal control, thus allowing definitive conclusions regarding the effects of Bcr/Abl expression.

In contrast, primary CML cells are heterogeneous with respect to lineage and stage of differentiation, and it is difficult to define an ideal normal cell population for comparison. In addition, it is difficult to control for possible cytokine secretion by stromal cells, macrophages, $\mathrm{T}$ lymphocytes, or even the leukemic cells themselves in these heterologous cultures. Nonetheless, we did find that adhesion of CML progenitor cells was elevated, compared with normal progenitor cells. We presume that this elevated adhesion is largely due to the presence of $\mathrm{Bcr} / \mathrm{Abl}$ in the CML cells.

Notably, integrin expression was unchanged in the Bcr/Abl transfectants. Also, integrin expression was unchanged in CML progenitors as compared with normal progenitors, as shown elsewhere (13). In addition, integrins from Bcr/Abl transfectants had normal electrophoretic mobility, suggestive of unaltered integrin maturation (not shown). These results indicate that $\mathrm{Bcr} / \mathrm{Abl}$ expression causes an alteration of inside-out signaling that regulates integrin function. The Bcr/Abl-dependent stimulation of adhesion was a particularly surprising observation, since inhibition of cell adhesion was predicted (see below). Also, impaired rather than enhanced cell adhesion is
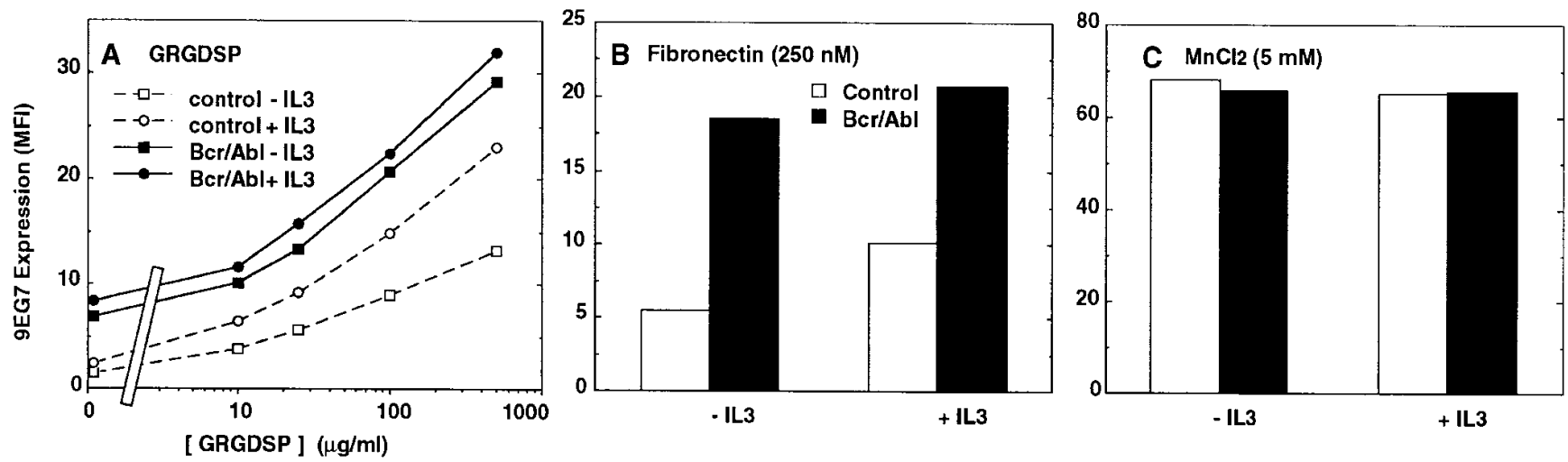

Figure 8. p210 Bcr/Abl and IL-3 both induce ligand binding. (A) Untransfected (open symbols) and p210 Bcr/Abl-transfected (closed symbols) $32 \mathrm{D}$ cells were cultured for $16 \mathrm{~h}$ either in absence (squares) or presence (circles) of IL-3 and then incubated with GRGDSP peptide before being analyzed for expression of the 9EG7 epitope by flow cytometry. The effect of soluble fibronectin $(B)$ and manganese $(C)$ on the 9EG7 epitope is also shown. 


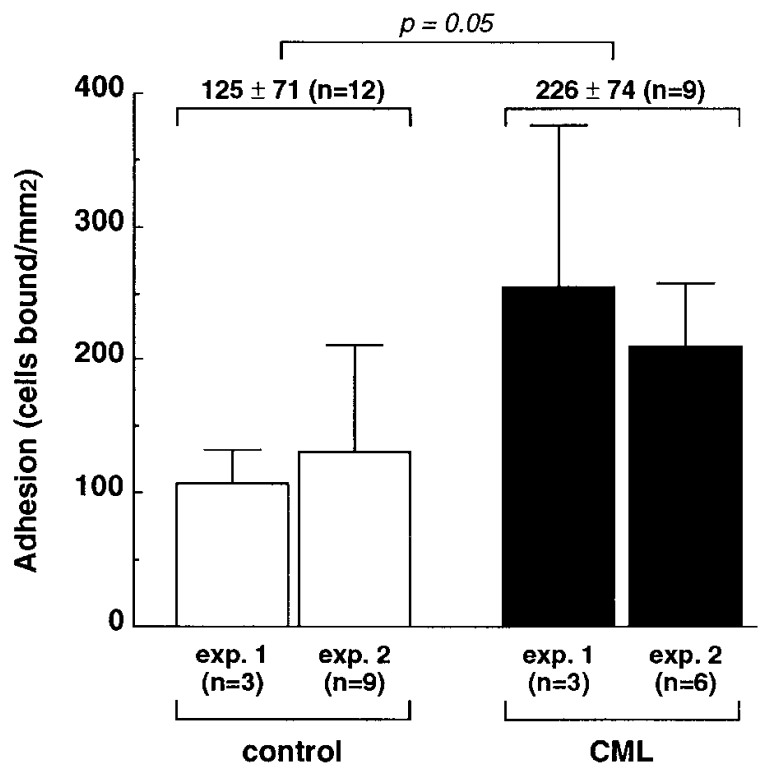

Figure 9. Adhesion of normal and CML hematopoietic precursors to fibronectin. $\mathrm{CD} 34^{+}$bone marrow cells from normal individuals (white bars) and CML patients (black bars) were tested for adhesion to fibronectin (coated at $10 \mu \mathrm{g} / \mathrm{ml}$ ) in a 30-min adhesion assay. Results are the mean \pm SD from two separate experiments, with the number of replicates indicated. The difference between control and CML cells was evaluated by the unpaired Student's $t$ test.

more commonly associated with oncogene expression or antioncogene suppression (33-35).

In one study, adhesion of CML bone marrow progenitors to purified fibronectin was suggested to be reduced compared with the adhesion of progenitors from normal donors (13). However, adhesion was evaluated indirectly by enumerating the number of colonies initiated by adherent cells after 3 and 5 wk in short- and long-term bone marrow cultures. At these time points, the number of colonies might not reflect differences in the initial adhesion, but rather in the subsequent expansion of the initiator cells $(36,37)$.

Parallel effects of Bcr/Abl and cytokines. Previously it was found that $\mathrm{Bcr} / \mathrm{Abl}$ expression triggers the growth (38) and survival (39) of hematopoietic precursor cells and cell lines, such that they become cytokine independent. Notably, stimulation of cell growth by $\mathrm{Bcr} / \mathrm{Abl}$ and cytokines may involve similar mechanisms. For example, Bcr/Abl (40) and cytokines such as IL-3 and GM-CSF (41) similarly regulate phosphatidylinositol-3 kinase activity. Also Bcr/Abl, GM-CSF, IL-3, and Steel factor show comparable triggering of phosphorylation of p95 ${ }^{\text {Vav }}$ in myeloid cells (42). Here we extend the parallel between Bcr/Abl and cytokines to show that Bcr/Abl can efficiently replace IL-3 and GM-CSF not only in promoting cell growth, but also in enhancing cell adhesion to fibronectin and VCAM-1. Indeed, adhesion of Bcr/Abl-transfected cells was approximately equivalent to that of untransformed cells that had been routinely cultured in the presence of IL-3 or GMCSF. Thus, Bcr/Abl expression mimics the inside-out signaling effects of IL-3 or GM-CSF on cell adhesion. As previously discussed (15), Bcr/Abl itself did not induce the synthesis of any detectable levels of cytokines in transfected 32D cells.

Notably, both Bcr/Abl and IL-3 stimulate adhesion with similar transient time courses, with a return to basal levels be- tween 2 and $6 \mathrm{~h}$ after initial attachment. Comparable transient integrin-mediated adhesion and deadhesion events have also been shown previously for cytokine-stimulated hematopoietic cells (28), and stimulated lymphocytes $(7,43)$ and neutrophils (44), where deadhesion is likely to involve phosphatase activities (45).

Effect of Bcr/Abl on ligand binding. Here we used the anti- $\beta_{1}$ antibody, mAb 9EG7, to demonstrate that $\mathrm{Bcr} / \mathrm{Abl}$ promotes VLA-5 binding to soluble fibronectin, and RGD peptide. From this we conclude that inside-out signaling involving $\mathrm{Bcr} /$ Abl leads to a change in the VLA-5 conformation that is favorable for ligand binding. This effect of Bcr/Abl may be similar to the increase in ligand binding resulting from inside-out signaling that has been described for $\alpha^{\mathrm{IIb}} \beta_{3}$ integrin in thrombinstimulated platelets (9). Although we have demonstrated that $\mathrm{Bcr} / \mathrm{Abl}$ can alter integrin ligand binding, we have not addressed other potential mechanisms for regulation of integrindependent cell adhesion. For example, it remains to be seen whether Bcr/Abl may contribute to cell adhesion by also enhancing post-ligand binding events such as integrin clustering and/or cell spreading.

It was found previously that cytokines such as IL-3 and GM-CSF could stimulate the adhesive functions of VLA-4 and VLA-5 (28), but ligand binding was not analyzed in those studies. Here we have shown that IL-3 stimulates the binding of soluble fibronectin and GRGDSP ligands to VLA-5, thus helping to explain why increased adhesive function was observed previously. Also, this result further emphasizes the parallel effects of $\mathrm{Bcr} / \mathrm{Abl}$ expression and cytokine stimulation.

Bcr/Abl tyrosine kinase activity and cell adhesion. Using a temperature-sensitive Bcr/Abl tyrosine kinase mutant (15), we showed that the induction of the kinase activity is strictly correlated with enhanced cell adhesion to fibronectin. Increased adhesiveness was observed as early as $6 \mathrm{~h}$ after switching to the permissive temperature and paralleled Bcr/Abl increased autophosphorylation, strongly suggesting a causal link. In this regard, protein kinase activity was shown previously to be essential for the adhesion-promoting effects of IL-3 and GM-CSF (28). In contrast to cell lines that constitutively overexpress a fully active form of $\mathrm{Bcr} / \mathrm{Abl}$ and accumulate chromosomal abnormalities at high rate (46), the biological properties of $\mathrm{Bcr} /$ Abl kinase-inducible transfectants are more likely to be consistent with the phenotype of primary CML progenitors. Our results do not exclude a role for other activities of Bcr/Abl, such as its actin-binding function, which is unaltered by our kinase mutation (47).

It seems unlikely that the VLA-5 integrin itself might be a substrate for the kinase activity of Bcr/Abl, since tyrosyl phosphorylation of the VLA-5 subunits was either undetectable $\left(\beta_{1}\right.$ subunit) or unaltered ( $\alpha^{5}$ subunit) in Bcr/Abl-transfected 32D cells (not shown). Alternatively, Bcr/Abl kinase could indirectly influence integrin function by targeting cytoskeletal molecules that associate with integrins (48). Indeed, there is a growing list of cytoskeletal and focal adhesion proteins now shown to be substrates of Bcr/Abl (49).

$B c r / A b l$-dependent integrin activation and $C M L$. It remains to be determined how the in vitro stimulatory effect of Bcr/ Abl described here in our simplified system might contribute to the pathologic functions of CML progenitors. The clinical phenotype of CML is characterized by premature and excessive release of progenitor cells from the marrow, and accumulation of myeloid cells in the blood and spleen. Interestingly, 
administration of IL-3 or GM-CSF or other cytokines results in a similar release of progenitor cells from the marrow, and striking accumulation of these cells in the blood $(50,51)$. Longterm administration of G-CSF has even been associated with accumulation of myeloid cells in the spleen with resulting benign splenomegaly (52). Thus, the parallels between the effects of hematopoietic growth factors and Bcr/Abl's effects on adhesion in vitro may extend to the in vivo situation as well.

A stromal layer is essential for the growth of normal and leukemic precursors (53). Also, fibronectin has an instructive and permissive effect on the proliferation and differentiation of erythroid (54), myeloid $(55)$, and lymphoid $(56,57)$ precursors, as well as on the in vivo medullary hematopoiesis (58). In addition, VCAM-1 may help to promote lympho- and myelopoiesis $(56,59)$. However, direct contact with the stroma may inhibit proliferation (60). This inhibition is overcome by blocking the VLA-4 interaction with fibronectin (61). These divergent findings suggest that adhesion may exert a dual control on the proliferation of hematopoietic cells; a transient contact might initiate proliferation, but a prolonged adhesion might inhibit growth. These observations lead us to speculate that the transient binding to fibronectin induced by $\mathrm{Bcr} / \mathrm{Abl}$ may promote rather than inhibit the growth of CML cells, but that these cells can subsequently escape from the negative influence of a prolonged contact with the matrix. Notably, insensitivity to the inhibition of growth exerted by stroma has been observed in precursors from polycythemia vera (62), a proliferative disorder that, unlike CML, is not associated with the $\mathrm{Bcr} / \mathrm{Abl}$ oncogene.

In conclusion, we have found that $\mathrm{p} 210 \mathrm{Bcr} / \mathrm{Abl}$ expression in hematopoietic cell lines stimulates integrin-dependent cell adhesion to fibronectin and VCAM-1. As a result, it may be necessary to reevaluate the mechanism for increased emigration of CML precursor cells since it is not obviously caused by defective integrin adhesive functions.

\section{Acknowledgments}

This work was supported by National Institutes of Health grants CA42368 to M.E. Hemler and CA66996 to J.D. Griffin. Dr. G. Bazzoni is currently supported by the American-Italian Cancer Foundation.

\section{References}

1. Hynes, R.O. 1992. Integrins: versatility, modulation and signalling in cell adhesion. Cell. 69:11-25.

2. Hemler, M.E. 1990. VLA proteins in the integrin family: structures, functions, and their role on leukocytes. Ann. Rev. Immunol. 8:365-400.

3. Giancotti, F.G., and E. Ruoslahti. 1990. Elevated levels of the $\alpha^{5} \beta_{1}$ fibronectin receptor suppress the transformed phenotype of Chinese hamster ovary cells. Cell. 60:849-859.

4. Zhang, Z.H., K. Vuori, J.C. Reed, and E. Ruoslahti. 1995. The $\alpha 5 \beta 1$ integrin supports survival of cells on fibronectin and up-regulates BCL-2 expression. Proc. Natl. Acad. Sci. USA. 92:6161-6165.

5. Marguerie, G.A., E.F. Plow, and T.S. Edgington. 1979. Human platelets possess an inducible and saturable receptor specific for fibrinogen. J. Biol. Chem. 254:5357-5363.

6. Van Kooyk, Y., P. Van DeWiel-Van Kemenade, P. Weder, T.W. Kuijpers, and C.G. Figdor. 1989. Enhancement of LFA-1-mediated cell adhesion by triggering through CD2 or CD3 on T lymphocytes. Nature (Lond.). 342: 811-813.

7. Dustin, M.L., and T.A. Springer. 1989. T-cell receptor cross-linking transiently stimulates adhesiveness through LFA-1. Nature (Lond.). 341:619-624.

8. Adams, J.C., and F.M. Watt. 1990. Changes in keratinocyte adhesion during terminal differentiation: reduction in fibronectin binding precedes $\alpha 5 \beta 1$ integrin loss from the cell surface. Cell. 63:425-435.

9. Ginsberg, M.H., X. Du, and E.F. Plow. 1992. Inside-out integrin signalling. Curr. Opin. Cell Biol. 4:766-771.
10. Nowell, P.C., and D.A. Hungerford. 1960. A minute chromosome in human chronic granulocytic leukemia. J. Natl. Cancer Inst. 25:85-109.

11. Lugo, T.G., A.M. Pendergast, A.J. Muller, and O.N. Witte. 1990. Tyrosine kinase activity and transformation potency of bcr-abl oncogene products. Science (Wash. DC). 247:1079-1082.

12. Gordon, M.Y., C.R. Dowding, G.P. Riley, J.M. Goldman, and M.F. Greaves. 1987. Altered adhesive interactions with marrow stroma of haematopoietic progenitor cells in chronic myeloid leukaemia. Nature (Lond.). 328:342344.

13. Verfaillie, C.M., J.B. McCarthy, and P.B. McGlave. 1992. Mechanisms underlying abnormal trafficking of malignant progenitors in chronic myelogenous leukemia. J. Clin. Invest. 90:1232-1241.

14. Matulonis, U.A., C. Dosiou, C. Lamont, G.J. Freeman, P. Mauch, L.M. Nadler, and J.D. Griffin. 1995. Role of B7-1 in mediating an immune response to myeloid leukemia cells. Blood. 85:2507-2515.

15. Carlesso, N., J.D. Griffin, and B.J. Druker. 1994. Use of a temperature sensitive mutant to define the biological effects of the p210 bcr/abl tyrosine kinase on proliferation of a factor-dependent murine myeloid cell line. Oncogene. 9:149-156.

16. Elices, M.J., L. Osborn, Y. Takada, C. Crouse, S. Luhowskyj, M.E. Hemler, and R.R. Lobb. 1990. VCAM-1 on activated endothelium interacts with the leukocyte integrin VLA-4 at a site distinct from the VLA-4/fibronectin binding site. Cell. 60:577-584.

17. Chan, B.M.C., M.J. Elices, E. Murphy, and M.E. Hemler. 1992. Adhesion to VCAM-1 and fibronectin: comparison of $\alpha 4 \beta 1$ (VLA-4) and $\alpha 4 \beta 7$ on the human cell line JY. J. Biol. Chem. 267:8366-8370.

18. Hemler, M.E., F. Sánchez-Madrid, T.J. Flotte, A.M. Krensky, S.J. Burakoff, A.K. Bhan, T.A. Springer, and J.L. Strominger. 1984. Glycoproteins of 210,000 and 130,000 m.w. on activated T cells: cell distribution and antigenic relation to components on resting cells and T cell lines. J. Immunol. 132:30113018.

19. Bergelson, J.M., N. St. John, S. Kawaguchi, R. Pasqualini, F. Berdichevsky, M.E. Hemler, and R.W. Finberg. 1994. The I domain is essential for echovirus 1 interaction with VLA-2. Cell Adh. \& Comm. 2:455-464.

20. Weitzman, J.B., R. Pasqualini, Y. Takada, and M.E. Hemler. 1993. The function and distinctive regulation of the integrin VLA-3 in cell adhesion, spreading and homotypic cell aggregation. J. Biol. Chem. 268:8651-8657.

21. Hemler, M.E., C. Huang, Y. Takada, L. Schwarz, J.L. Strominger, and M.L. Clabby. 1987. Characterization of the cell surface heterodimer VLA-4 and related peptides. J. Biol. Chem. 262:11478-11485.

22. Lee, R.T., F. Berditchevski, G.C. Cheng, and M.E. Hemler. 1995. Integrin-mediated collagen matrix reorganization by cultured human vascular smooth muscle cells. Circ. Res. 76:209-214.

23. Hemler, M.E., C.F. Ware, and J.L. Strominger. 1983. Characterization of a novel differentiation antigen complex recognized by a monoclonal antibody (A-1A5): unique activation-specific molecular forms on stimulated T cells. J. Immunol. 131:334-340.

24. Akiyama, S.K., S.S. Yamada, W.-T. Chen, and K.M. Yamada. 1989. Analysis of fibronectin receptor function with monoclonal antibodies: roles in cell adhesion, migration, matrix assembly, and cytoskeletal organization. J. Cell Biol. 109:863-875.

25. Lenter, M., H. Uhlig, A. Hamann, P. Jeno, B. Imhof, and D. Vestweber. 1993. A monoclonal antibody against an activation epitope on mouse integrin chain $\beta 1$ blocks adhesion of lymphocytes to the endothelial integrin $\alpha 6 \beta 1$. Proc. Natl. Acad. Sci. USA. 90:9051-9055.

26. Hemler, M.E., and J.L. Strominger. 1982. Monoclonal antibodies reacting with immunogenic mycoplasma proteins present in human hematopoietic cell lines. J. Immunol. 129:2734-2738.

27. Avanzi, G.C., P. Lista, B. Giovinazzo, G. Miniero, G. Saglio, R. Benetton, G. Coda, and L. Pegoraro. 1988. Selective growth response to IL-3 of a human leukaemic cell line with megakaryoblastic features. Br. J. Haematol. 69: 359-366.

28. Levesque, J.P., D.I. Leavesley, S. Niutta, M. Vadas, and P.J. Simmons. 1995. Cytokines increase human hemopoietic cell adhesiveness by activation of very late antigen (VLA)-4 and VLA-5 integrins. J. Exp. Med. 181:1805-1815.

29. Greenberger, J.S., M.A. Sakakeeny, R.K. Humphries, C.J. Eaves, and R.J. Eckner. 1983. Demonstration of permanent factor-dependent multipotential (erythroid/neutrophil/basophil) hematopoietic progenitor cell lines. Proc. Natl. Acad. Sci. USA. 80:2931-2935.

30. Palacios, R., and M. Steinmetz. 1985. IL-3-dependent mouse clones that express B-220 surface antigen contain Ig genes in germ line configuration and generate B-lymphocytes in vivo. Cell. 41:727-734.

31. Faull, R.J., N.L. Kovach, J.M. Harlan, and M.H. Ginsberg. 1994. Stimulation of integrin-mediated adhesion of $\mathrm{T}$ lymphocytes and monocytes: two mechanisms with divergent biological consequences. J. Exp. Med. 179:13071316.

32. Bazzoni, G., D.-T. Shih, C.A. Buck, and M.E. Hemler. 1995. MAb 9EG7 defines a novel $\beta_{1}$ integrin epitope induced by soluble ligand and manganese, but inhibited by calcium. J. Biol. Chem. 270:25570-25577.

33. Plantefaber, L.C., and R.O. Hynes. 1989. Changes in integrin receptors on oncogenically transformed cells. Cell. 56:281-290.

34. Navarro, P., M. Gomez, A. Pizarro, C. Gamallo, M. Quintanilla, and A. 
Cano. 1991. A role for the E-cadherin cell-cell adhesion molecule during tumor progression of mouse epidermal carcinogenesis. J. Cell Biol. 115:517-533.

35. Narayanan, R., K.G. Lawlor, R.Q. Schaapveld, K.R. Cho, B. Vogelstein, T.P. Bui-Vinh, M.P. Osborne, and N.T. Telang. 1992. Antisense RNA to the putative tumor-suppressor gene DCC transforms Rat-1 fibroblasts. Oncogene. 7:553-561.

36. Coulombel, L., D.K. Kalousek, C.J. Eaves, C.M. Gupta, and A.C. Eaves. 1983. Long-term marrow culture reveals chromosomally normal hematopoietic progenitor cells in patients with Philadelphia chromosome-positive chronic myelogenous leukemia. N. Engl. J. Med. 308:1493-1498.

37. Dubé, I.D., D.K. Kalousek, L. Coulombel, C.M. Gupta, C.J. Eaves, and A.C. Eaves. 1984. Cytogenetic studies of early myeloid progenitor compartments in Ph1-positive chronic myeloid leukemia. II. Long-term culture reveals the persistence of Ph1-negative progenitors in treated as well as newly diagnosed patients. Blood. 63:1172-1177.

38. Daley, G.Q., and D. Baltimore. 1988. Transformation of an interleukin 3-dependent hematopoietic cell line by the chronic myelogenous leukemia-specific P210 ${ }^{\mathrm{bcr} / \mathrm{abl}}$ protein. Proc. Natl. Acad. Sci. USA. 85:9312-9316.

39. Bedi, A., B.A. Zehnbauer, J.P. Barber, S.J. Sharkis, and R.J. Jones. 1994. Inhibition of apoptosis by BCR-ABL in chronic myeloid leukemia. Blood. 83:2038-2044.

40. Skorski, T., P. Kanakaraj, M. Nieborowska-Skorska, M.Z. Ratajczak, S.-C. Wen, G. Zon, A.M. Gewirtz, B. Perussia, and B. Calabretta. 1995. Phosphatidylinositol-3 kinase activity is regulated by $\mathrm{BCR} / \mathrm{ABL}$ and is required for the growth of Philadelphia chromosome-positive cells. Blood. 86:726-736.

41. Corey, S., A. Eguinoa, K. Puyana-Theall, J.B. Bolen, L. Cantley, F. Mollinedo, T.R. Jackson, P.T. Hawkins, and L.R. Stephens. 1993. Granulocyte macrophage-colony stimulating factor stimulates both association and activation of phosphoinositide 3OH-kinase and Src-related tyrosine kinase(s) in human myeloid derived cells. EMBO (Eur. Mol. Biol. Organ.) J. 12:2681-2690.

42. Matsuguchi, T., R.C. Inhorn, N. Carlesso, G. Xu, B. Druker, and J.D. Griffin. 1995. Tyrosine phosphorylation of $\mathrm{p} 95^{\mathrm{Vav}}$ in myeloid cells is regulated by GM-CSF, IL-3 and Steel factor and is constitutively increased by $\mathrm{p} 210^{\mathrm{BCR} / \mathrm{ABL}}$. EMBO (Eur. Mol. Biol. Organ.) J. 14:257-265.

43. Chan, B.M.C., J. Wong, A. Rao, and M.E. Hemler. 1991. T cell receptor dependent, antigen specific stimulation of a murine $\mathrm{T}$ cell clone induces a transient VLA protein-mediated binding to extracellular matrix. J. Immunol. 147: 398-404.

44. Lo, S.K., P.A. Detmers, S.M. Levin, and S.D. Wright. 1989. Transient adhesion of neutrophils to endothelium. J. Exp. Med. 169:1779-1793.

45. Wright, S.D., and B.C. Meyer. 1986. Phorbol esters cause sequential activation and deactivation of complement receptors on polymorphonuclear leukocytes. J. Immunol. 136:1759-1764.

46. Laneuville, P., G. Sun, M. Timm, and M. Vekemans. 1992. Clonal evolution in a myeloid cell line transformed to interleukin-3 independent growth by retroviral transduction and expression of p210 bcr/abl. Blood. 80:1788-1797.

47. McWhirter, J.R., and J.Y.J. Wang. 1993. An actin binding function contributes to transformation by the Bcr-Abl oncoprotein of Philadelphia chromosome-positive human leukemias. EMBO (Eur. Mol. Biol. Organ.) J. 12:15331546.
48. Burridge, K., K. Fath, T. Kelly, G. Nuckolls, and C. Turner. 1988. Focal adhesions: transmembrane junctions between the extracellular matrix and the cytoskeleton. Ann. Rev. Cell Biol. 4:487-525.

49. Salgia, R., J.-L. Li, S.H. Lo, B. Brunkhorst, G.S. Kansas, E.S. Sobhany, Y. Sun, E. Pisick, M. Hallek, T. Ernst, R. Tantravahi, L.B. Chen, and J.D. Griffin. 1995. Molecular cloning of human paxillin, a focal adhesion protein phosphorylated by $\mathrm{P} 210^{\mathrm{BCR} / \mathrm{ABL}}$. J. Biol. Chem. 270:5039-5047.

50. Socinski, M.A., S.A. Cannistra, A. Elias, K.H. Antman, L. Schnipper, and J.D. Griffin. 1988. Granulocyte-macrophage colony stimulating factor expands the circulating hematopoietic progenitor cell compartment in humans. Lancet. 1:1194-1198.

51. Duhrsen, U., J.L. Villeval, J. Boyd, G. Kannourakis, G. Morstyn, and D. Metcalf. 1988. Effects of recombinant human granulocyte colony-stimulating factor on hematopoietic progenitor cells in cancer patients. Blood. 72:20742081.

52. Bonilla, M.A., D. Dale, C. Zeidler, L. Last, A. Reiter, M. Ruggeiro, M. Davis, B. Koci, W. Hammond, A. Gillio, and K. Welte. 1994. Long-term safety of treatment with recombinant human granulocyte colony-stimulating factor (r-metHuG-CSF) in patients with severe congenital neutropenias. Br. J. Haematol. 88:723-730.

53. Dexter, T.M, T.D. Allen, and L.G. Lajtha. 1977. Conditions controlling the proliferation of hemopoietic stem cells in vitro. J. Cell Physiol. 91:335-344.

54. Weinstein, R., M.A. Riordan, K. Wenc, S. Kreczko, and N. Dainiak. 1989. Dual role of fibronectin in hematopoietic differentiation. Blood. 73:111116

55. Campbell, A.D., M.W. Long, and M.S. Wicha. 1985. Extracellular matrix promotes the growth and differentiation of hematopoietic cells in long-term marrow cultures. J. Clin. Invest. 75:2085-2092.

56. Miyake, K., I.L. Weissman, J.S. Greenberger, and P.W. Kincade. 1991. Evidence for a role of the integrin VLA-4 in lympho-hemopoiesis. J. Exp. Med. 173:599-607.

57. Dittel, B.N., J.B. McCarthy, E.A. Wayner, and T.W. LeBien. 1993. Regulation of human B-cell precursor adhesion to bone marrow stromal cells by cytokines that exert opposing effects on the expression of vascular cell adhesion molecule-1 (VCAM). Blood. 81:2272-2282.

58. Williams, D.A., M. Rios, C. Stephens, and V.P. Patel. 1991. Fibronectin and VLA-4 in haematopoietic stem cell-microenvironment interactions. Nature (Lond.). 352:438-441.

59. Teixidó, J., M.E. Hemler, J.S. Greenberger, and P. Anklesaria. 1992. Role of $\beta_{1}$ and $\beta_{2}$ integrins in the adhesion of human CD34 ${ }^{\text {hi }}$ stem cells to bone marrow stroma. J. Clin. Invest. 90:358-367.

60. Verfaillie, C.M. 1992. Direct contact between human primitive hematopoietic progenitors and bone marrow stroma is not required for long-term in vitro hematopoiesis. Blood. 79:2821-2826.

61. Hurley, R.W., J.B. McCarthy, and C.M. Verfaillie. 1995. Direct adhesion to bone marrow stroma via fibronectin receptors inhibits hematopoietic progenitor proliferation. J. Clin. Invest. 96:511-519.

62. Cashman, J.D., C.J. Eaves, and A.C. Eaves. 1988. Unregulated proliferation of primitive neoplastic progenitor cells in long-term polycythemia vera marrow cultures. J. Clin. Invest. 81:87-91. 